\title{
Behaviour of ribosomal genes and nucleolar domains during activation in sugarcane (Saccharum officinarum L.) root primordia: from the unsoaked quiescent state to the steady state of proliferation*
}

\author{
R. Acevedo, A. Cuadrado', C. De la Torre and S. Moreno Díaz de la Espina \\ Centro de Investigaciones Biológicas, CSIC. Madrid, Spain and 'Departamento de Biología Celular y Genética, Uni- \\ versidad de Alcalá de Henares, Madrid, Spain
}

Accepted: 30/4/2002

Key words: Saccharum officinarum, root primordia, activation and proliferation, ribosomal genes, flow cytometry, FISH, silver staining, electron microscopy

\section{SUMMARY}

Changes in the organisation of ribosomal genes and nucleolar protein components were analysed in sugarcane (Saccharum officinarum L. cv Cristalina) from the time the quiescent primordia of the radical bands of nodes were stimulated to proliferate by water imbibition, until the meristematic population reached the steady state of proliferation in the growing roots. The kinetics of proliferation was evaluated by flow cytometry, and by the mitotic indexes, in roots of different lengths. All the quiescent cells were in a pre-replicative state $\left(\mathrm{G}_{0}\right)$, with a $2 \mathrm{C}$ DNA content. During their activation process, they progressively reached the steady state of proliferation (mitotic index 7\%), with rather fixed frequencies for cells with 2C (G1), 4C (G2), and values between them corresponding to cells replicating their DNA. Decondensation of the ribosomal genes was followed by FISH with probes for the major $25 \mathrm{~S}$ and $18 \mathrm{~S}$ rRNAs, and variations in the numbers of nucleoli were recorded in squashed cells after silver staining. The ultrastructure of nucleoli was analysed by electron microscopy, using the EDTA regressive staining for ribonucleoproteins. Quiescent nucleoli showed a clear segregation of their main components: Fibrillar Centre, Dense Fibrillar Component and Cajal's bodies while lacked any Granular Component. However the proliferating ones showed them highly intermingled, except for the Cajal's bodies. Our results revealed a high plasticity of the nucleolar domains in response to cell activation, and allowed to establish a correlation between dispersion of NORs with formation of small fibrillar centers and a nucleolus with all its domains intermingled, and the activation of cell proliferation during root sprouting.

\section{INTRODUCTION}

During the vegetative propagation of sugarcane by stem portions, two types of roots are produced. First the roots from the quiescent primordia of the radical band of the nodes, and later the roots of the buds. The life span of the first ones is limited, but the sprouting cane and, therefore, the future development of the plant is dependent on them. The

*This paper is dedicated to our collegue and friend Dr M.E. Fernández Gómez on the occasion of her retirement.

Correspondence to: S. Moreno Diaz de la Espina. E-mail: smoreno@cib.csic.es 
proliferative activity of these roots is localised in a group of cells, already present in the quiescent root as primordia. They give rise to the future meristem, which will remain mitotically active during the life span of the roots, and eventually to the roots of the bands. The meristem is a structural territory obeying strict rules of development, and the cells in the quiescent meristem experience a process of genetic activation accompanied by a simultaneous evolution of the nuclear organisation after their imbibition in water (Sans et al., 1980; Sussex, 1978). The onset of cell activation and proliferation in a previously dormant tissue is an interesting model to analyse the changes of nuclear organisation associated to the activation process. For these reasons, the developing root primordium constitutes a good system to find out a correlation between nucleolar activity and ultrastructural organization during plant cell development.

The structure of the nucleolus is organised around the tandemly repeats of rDNA genes, which form the chromosomal nucleolar organising region (NORs) during mitosis. In spite of the specific differences observed in the number and chromosomal location of rDNA copies and NORs, and also in their expression, specially in plants in which the nucleolar dominance is relatively common (Reder, 1985; Panzera et al., 1996), the active nucleolus in eukaryotes follows a general pattern of organisation with three universal domains. The first is the fibrillar centre (FC) which contains ribosomal genes. Transcription of the rDNA genes occurs at its periphery and generates two other general domains of the active nucleolus: the dense fibrillar component (DFC) which contains the newly synthesised pre-rRNA associated with proteins and the granular component (GC) containing the assembled pre-ribosomal particles to be exported to the cytoplasm (Olson et al., 200; Medina et al., 2000). This canonical organisation of the active eukaryotic nucleolus is highly dynamic and sensitive to changes in the rates of both transcription and assembly of pre-ribosomal particles either physiological or experimentally induced. Highly active nucleoli are large and show extensive intermingling of the three domains, while inactive nucleoli are small and compact and their domains are segregated (Risueño and Moreno Díaz de la Espina, 1979; Medina et al., 1983; Martín et al., 1989; Bassy et al., 2000; Medina et al., 2000). The nucleolus is also involved in cell activities not related with ribosome biogenesis, as the assembly and processing of small RNP particles like the signal recognition particle (SRP), telomerase, U6 splicing particle and tRNA particles (Pederson, 1998; Olson et al., 2000). Some of these functions appear to be related with the nucleolus-associated Cajal's bodies (CBs: Olson et al., 2000; Acevedo et al., 2002).

In plants the rate of ribosome biogenesis is regulated during cell cycle, increasing from $\mathrm{G}_{1}$ to $\mathrm{G}_{2}$ and peaks just before nucleolus disassembles before mitosis (de la Torre and Giménez-Martín, 1982) and factors stimulating cell growth and division have been demonstrated to regulate the rate of ribosome biogenesis (Karagiannis and Pappelis, 1994; Gaudino and Pikaard, 1977). In the last decade the development of fluorescence in situ hybridization (FISH) and high resolution in situ hybridisation (HRISH) led to a great advance in the investigation of ribosomal gene organisation and expression in different plant species (Motte et al., 1991; Leicht et al., 1992; Highett et al., 1993, Panzera et al., 1996; Thompson et al., 1997; Bassy et al., 2000).

Although some studies have been performed on the sequential variations of nucleolar activity and organisation during the sprouting of roots mainly in seeds (Deltour, 1985; Melera, 1971; Medina et al., 1983; Bryant, 1969; Jakob and Bovey, 1969; Fakan and Deltour, 1981; van de Walle and Bernier, 1969), the analysis of the distribution and activity of the ribosomal genes during this process was not undertaken until recently in three species: corn, pea (Mineur et al., 1998) and onion (Bassy et al., 2000).

Here we analysed by FISH the distribution of ribosomal genes in chromosomes of the sugarcane (Saccharum officinarum cv. Cristalina), their organization in interphase in quiescent root primordia and their decondensation during the process of cell activation by water imbibition. The kinetics of activation of the quiescent meristem was evaluated by flow cytometry and by the mitotic indexes recorded in roots of different lengths. The ultrastructural organization of nucleolar domains during the process was analysed by electron microscopy and these results correlated with those obtained by FISH and immunostaining with antibodies against nucleolar protein components as fibrillarin and splicing factors. 


\section{MATERIAL AND METHODS}

\section{Materials}

Sugarcane (Saccharum officinarum cv. Cristalina) stalks, supplied by INICA (Cuba) were used. Stem sugarcane cuttings containing radicle bands were cultured on wet filter paper and cotton, in a Refritherm-5 (Struers) incubator at $30^{\circ} \mathrm{C}$ with a $85 \%$ relative humidity, under dark conditions. Samples of quiescent primordia were excised from the radical bands before soaking and $24 \mathrm{~h}$ after humidity. Roots of 2, 5, 7 and $15 \mathrm{~mm}$ lengths were also taken.

\section{Flow cytometry}

Primordia and proliferative roots $(2,5$ and $15 \mathrm{~mm}$ long) were fixed in $1 \%$ paraformaldehyde in Tris buffer $(10 \mathrm{mM}$ Tris, $10 \mathrm{mM} \mathrm{Na} \mathrm{EDDT}$, $100 \mathrm{mM}$ $\mathrm{NaCl} \mathrm{pH} \mathrm{7.5),} \mathrm{washed} \mathrm{in} \mathrm{the} \mathrm{same} \mathrm{buffer} \mathrm{and} \mathrm{digest-}$ ed with an enzyme mixture: $2 \%$ cellulase (Serva, Heidelberg), $1 \%$ pectinase, $0.05 \%$ macerozyme (Serva, Hiedelberg) and 0.4M mannitol (Merck, Darmstadt). Nuclei were isolated by using an Ultra Turrax homogeniser and $500 \mu 1$ lysis buffer $(15 \mathrm{mM}$ Tris, $2 \mathrm{mM} \mathrm{Na} \mathrm{NDDTA}_{2} 80 \mathrm{mM} \mathrm{KCl}, 20 \mathrm{mM} \mathrm{NaCl}$, $0.1 \%$ Triton $\mathrm{X}-100, \mathrm{pH} 7.5)$. The homogenate was filtered through a $30 \mu \mathrm{m}$ nylon mesh and centrifuged at $600 \mathrm{~g}$ for $20 \mathrm{~min}$ at $4^{\circ} \mathrm{C}$. Pellets were resuspended in $500 \mu \mathrm{l}$ lysis buffer. Propidium iodide $(0.1 \mathrm{mg} / \mathrm{ml})$ and DNase-free ribonuclease A (Serva, Hiedelberg) were then added. Salmo trutta erythrocytes were used as a standard. Samples were analysed with an EPICS XL (Coulter, FL., USA) flow cytometer. The frequency of cells in the different stages of the cycle were compared by automatic integration of all cells accumulated in a cycle segment between two chosen DNA contents by using the software XL version System II analysis.

\section{Mitotic index determination \\ Feulgen technique}

Primordia and proliferative roots $(1,2,4,5$ and 15 $\mathrm{mm}$ long) were fixed in ethanol-acetic acid (3:1) for $24 \mathrm{~h}$. Fixed samples were re-hydrated in water for $15 \mathrm{~min}$, incubated in $5 \mathrm{~N} \mathrm{HCl}$ solution at $20^{\circ} \mathrm{C}$ for $15 \mathrm{~min}$, washed in water, maintained in Schiff's reagent for $45 \mathrm{~min}$, and then washed in $5 \mathrm{~N} \mathrm{HCl}$ containing $10 \%$ sodium metabisulphite. After two water washes, samples were digested with the same enzyme mixture used for flow cytometry samples. Root tips were squashed onto clean microscope slides in a drop of $45 \%$ acetic acid, and mounted as previously reported (Sans et al., 1980).

Slides were observed by optical microscopy and the mitotic index estimated as the percentage of mitotic cells in relation to total meristematic cells. Five roots from each experiment were used and 1,500 cells per sample were counted.

\section{Silver staining of nucleolar proteins}

Batches of at least 20 roots from unsoaked and soaked primordia, and grown roots of different lengths were fixed for $2 \mathrm{~h}$ in a $1: 1(\mathrm{v} / \mathrm{v})$ mixture of $10 \%$ formaldehyde and $1 \%$ hydroquinone, at room temperature. After washing three times in distilled water for $10 \mathrm{~min}$, they were kept overnight in a $2 \%$ aqueous solution of $\mathrm{AgNO}_{3}$ at $70^{\circ} \mathrm{C}$, in the dark. After a further washing the roots were placed again in the formaldehyde-hydroquinone mixture for $1 \mathrm{~h}$. Afterwards, roots were squashed and mounted on gelatin-covered slides as previously described (Panzera et al., 1996).

\section{Statistical analysis}

The numbers of nucleoli per nucleus were counted in at least 200 cells from five separate preparations of quiescent, $5 \mathrm{~mm}$ and $15 \mathrm{~mm}$ roots. The data were analysed by testing equality between percentages compared two by two and by ANOVA followed by the Newman-Keuls test (Sokal and Rohlf, 1969).

\section{In situ hybridization.}

Quiescent and proliferative roots were fixed in 4\% paraformaldehyde in PBS pH 7.4 buffer. After washing in water to remove fixative, root tips were digested with an enzyme solution containing $2 \mathrm{ml}$ of $2 \%$ cellulase (Onozuka R10, Yakult Honsha Co., Tokyo) and 20\% liquid pectinase (from Aspergillus niger, Sigma Chemical Co., St. Louis, $\mathrm{Mo}$ ), for $50 \mathrm{~min}$ at $37^{\circ} \mathrm{C}$. The fixed root tips were squashed onto clean microscope slides in a drop of $45 \%$ acetic acid as previously described (Panzera et al., 1996). The samples were washed again in the above buffer, before freezing the slides to remove the cover, and were finally air-dried.

\section{DNA probes}

The DNA probes employed were: pTa71, a $9 \mathrm{~Kb}$ fragment from Triticum aestivum L. containing the $18 \mathrm{~S}-5.8 \mathrm{~S}-25 \mathrm{~S}$ rDNA and intergenic spacers 
(Gerlach and Bedbrook 1979), and pTa794, a 410 bp fragment from Triticum aestivum L. containing the 5S rDNA and the intergenic spacer (Gerlach and Dyer, 1980). The probes were labelled with digoxigenin-11-dUTP or rhodamine-4-dUTP by nick translation. The digoxigenin was detected using anti-digoxigenin FITC conjugate (green).

\section{Fluorescence in situ hybridization}

Preparations were incubated in $100 \mathrm{mg} / \mathrm{ml}$ DNase-free RNase in $2 \mathrm{x}$ saline sodium citrate (SSC) $(0.03 \mathrm{M} \mathrm{Na}$ citrate and $0.3 \mathrm{M} \mathrm{NaCl})$ for $1 \mathrm{~h}$ at $37^{\circ} \mathrm{C}$. The slides were then washed in $2 \times \mathrm{SSC}$ for $5 \mathrm{~min}$, post-fixed in freshly depolymerized $4 \%$ (w/v) paraformaldehyde in water for $10 \mathrm{~min}$, washed in $2 \times$ SSC for $10 \mathrm{~min}$, dehydrated in a graded ethanol series, and air dried.

Preparations and probe denaturation, in situ hybridisation, post-hybridisation washing and detection were all performed as previously described (Panzera et al., 1996).

Microscopy analyses were made in an epifluorescence Axiophot Zeiss system. Photographs were taken with Fuji Super G 400 ASA colour film. For the Figures, negatives were digitised and processed by using Photoshop 5.0 software by Adobe, with only those functions that applied equally to all pixels in the image.

\section{Fluorescence immunostaining Antibodies}

The primary antibodies employed were: 4G3 (1:5), a mouse monoclonal (Organon Teknica) recognizing the spliceosomal protein U2B" in plants (Boudonck et al. 1998); Y12 (undiluted) a mouse monoclonal recognising $\mathrm{Sm}$ protein $\mathrm{B}$ in plants (Vázquez-Nin et al. 1992), and S4 (1:200) a human autoimmune serum against fibrillarin recognising the plant protein (Moreno Díaz de la Espina 1995). Antimouse and antihuman antibodies conjugated to FITC (1:100) (Sigma) or Cy2 (1:200) were used as secondary antibodies.

\section{Confocal microscopy}

Quiescent and proliferative root meristems were fixed in 4\% paraformaldehyde in PEM buffer (50 $\mathrm{mM}$ PIPES, $5 \mathrm{mM} \mathrm{MgSO}_{4}$ and $5 \mathrm{mM}$ EGTA) $\mathrm{pH}$ $7.0,1 \mathrm{~h}$ at room temperature and washed $3 \times 15 \mathrm{~min}$ in the same buffer. After digestion with $2 \%$ cellulase R-10 and 20\% liquid pectinase (from Aspergillus niger, Sigma Chemical Co., St. Louis, Mo), for 50 min at $37^{\circ} \mathrm{C}$ in MAN buffer (0.4 M D-mannitol, 5mM EGTA, $1 \mu \mathrm{g} / \mathrm{ml}$ Triton $\mathrm{X}-100$ and $0.3 \mathrm{mM}$ PMSF) $\mathrm{pH} 7.0$, and washing $3 \times 15$ min in PEM buffer, root segments were squashed on $0.1 \%$ polyL-lysine-coated slides and solid residues were discarded. Cellular preparations were air-dried and kept at $-20^{\circ} \mathrm{C}$ until use. After quenching aldehyde groups with a freshly prepared $1 \mathrm{mg} / \mathrm{ml} \mathrm{NaBH}_{4}$ solution in PBS pH 8.0, 3x15 min, the slides were blocked and incubated with the primary and secondary antibodies as previously described (Acevedo et al., 2002). Experiments omitting the incubation with the primary antibody were performed as negative controls. After labelling, preparations were stained with $1 \mu \mathrm{g} / \mathrm{ml}$ DAPI or $10 \mu \mathrm{g} / \mathrm{ml}$ propidium iodide before mounting.

Preparations were examined with a MCR 1024 BioRad confocal system (BioRad, Richmond, CA) mounted on a Zeiss Axiovert 135 microscope (Zeiss, Oberkochen, Germany) equipped with a x63, 1.4 NA planapochromatic immersion objective.

\section{Electron microscopy}

For conventional electron microscopy, roots were fixed in $2 \%$ glutaraldehyde in $0.025 \mathrm{M}$ cacodylate buffer $\mathrm{pH} 7.2$ for $1 \mathrm{~h}$, postfixed in $1 \%$ osmium tetroxide in the same buffer, dehydrated in an ethanol series embedded in LRW resin and contrasted as previously described (Acevedo et al., 2002).

\section{Cytochemical staining}

Bernhard's EDTA regressive staining was performed in sections from samples fixed only in 3\% glutaraldehyde and further processed as previously described (Acevedo et al., 2002).

\section{RESULTS}

\section{Activation of the quiescent cells by water imbi- bition}

The quiescent primordium of the unsoaked roots is formed by one or two layers of undifferentiated cells located below the peripheral vacuolated cells of the quiescent root in semithin sections (data not shown). The quiescent meristematic cells were dense and small, had no vacuoles and were clearly distinct from those cells in the surrounding tissues of the root. Flow cytometry and cytological 


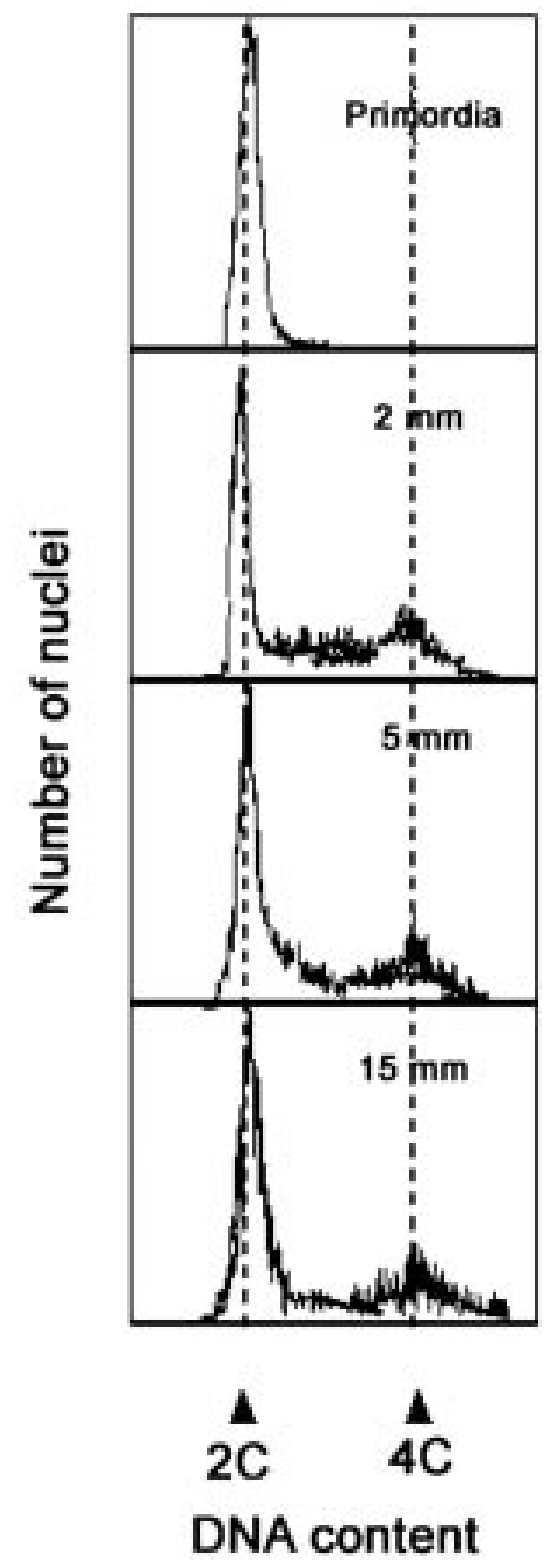

Fig. 1 - Evaluation of the cell cycle distribution of cells in quiescent primordia and proliferating roots of different lengths, by flow cytometry of the corresponding isolated nuclei after PI staining. The $2 \mathrm{C}$ peak corresponds to cells with a prereplicative DNA content, i.e. $\mathrm{G}_{0}$ in the quiescent primordia and $\mathrm{G}_{1}$ in the proliferating roots, the $4 \mathrm{C}$ peak to those in $\mathrm{G}_{2}$ and those with intermediate values reflect the $\mathrm{S}$ phase population.

analysis confirmed that the meristematic cells of the unsoaked meristem were neither cycling nor dividing (Fig. 1, 2A).

The passage of cells from the non-proliferative to the proliferative compartments, and the cell cycle distribution of the cells in the dormant root primordia and during the sprouting process were investigated by flow cytometry, and reinforced by estimating the corresponding mitotic indexes in squashed roots after Feulgen staining (Fig. 1, 2A to D).

Fig. 1 shows that most of the cells of the quiescent primordia were in a $G_{0}$ state with a prereplicative (2C) DNA content of $6 \mathrm{pg}$, the same DNA content that nuclei have in the $\mathrm{G}_{1}$ period of the proliferating meristems. The cells started activation after soaking with the same DNA content and in the same period of the cell cycle, and thus the activation would occur more or less synchronously, in contrast with the situation in other plant systems, in which both $\mathrm{G}_{0}$ and $\mathrm{G}_{02}$ cells were present in the quiescent primordia (Sans et al., 1980, Vant'Hof, 1974). After soaking, cells re-started cell cycle and entered asynchronously in the $\mathrm{S}$ phase. The percentages of nuclei with a DNA content above the $2 \mathrm{C}$ value increased, while those in the $\mathrm{G}_{1}$ decreased, and in the $2 \mathrm{~mm}$-root an accumulation of nuclei with a 4C DNA content, corresponding to $\mathrm{G}_{2}$, was observed. In the $5 \mathrm{~mm}$-root meristem an equilibrium between the relative amounts of $2 \mathrm{C}$ and $4 \mathrm{C}$ peaks was achieved. It was maintained later on in the meristematic population of the growing root, as shown here in the $15 \mathrm{~mm}$ roots (Fig. 1).

To estimate the kinetics of entry into mitosis of the quiescent cells of the primordia after soaking, the mitotic indexes were calculated in quiescent unsoaked roots and in roots of different lengths (Fig. 2A to B). Mitotic cells were never observed in the quiescent primordia (Fig. 2A). An accumulation of prophases was observed in the primordium of the freshly sprouted and grown roots until 1 $\mathrm{mm}$ length (Fig. 2B). The later presented a $4 \%$ of mitotic cells and the meristematic population reached the steady state equilibrium in the $4 \mathrm{~mm}$ root (Fig. 2C, D).

\section{Organisation of ribosomal gene clusters in chromosomes and nucleoli}

The total number and location of rDNA clusters in the sugarcane chromosomes were analysed in squashed metaphase cells of proliferating roots by FISH, using the probe pTa71. Eight NOR (18S$5.8 \mathrm{~S}-25 \mathrm{~S})$ sites were localised in terminal positions of eight chromosomes of the total $(2 n=80)$ chromosomes of the cell. Different NORs exhibit- 

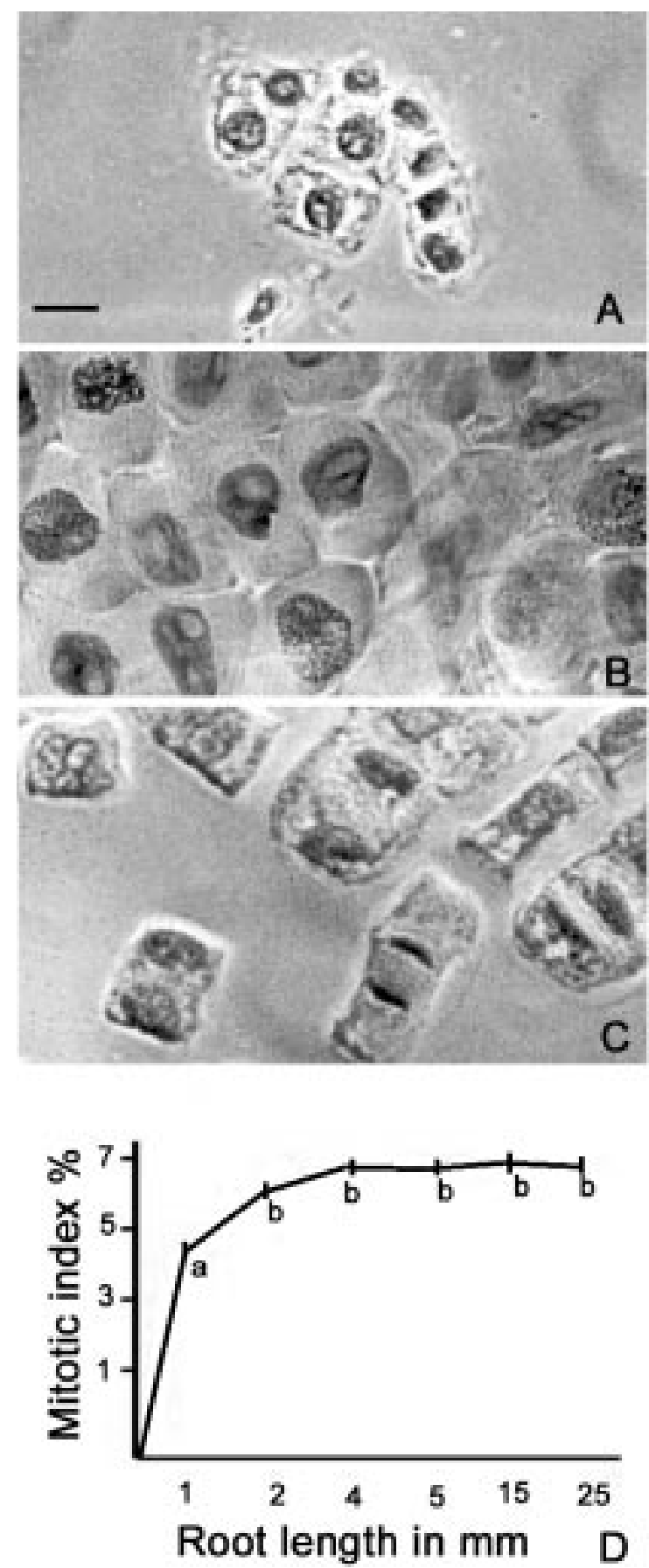

Fig. 2 - Mitotic indexes for roots of different sizes . A to C Micrographs after Feulgen staining showing portions of the squashed meristems in the dry primordia (A), after $24 \mathrm{~h}$ of water imbibition (B) and in the $15 \mathrm{~mm}$ root (C). Notice the dense chromatin in the nuclei of the quiescent meristem, the accumulation of prophases in B and the presence of mitotic figures in the proliferating root. Bars represent $10 \mu \mathrm{m}$. D. Mitotic indexes for roots of different lengths. ed different labeling intensities. Thus, three of them were clearly larger than the rest, three were intermediate and the two other displayed minor signals, suggesting an unbalanced distribution of the full complement of ribosomal copies between them (Fig. 3A). On the other hand, eight 5S rDNA sites were localised with the probe pTa794 at interstitial positions on 8 chromosomes that were different from those bearing the NORs (Fig. 3B).

The use of $4 \%$ paraformaldehyde fixation before FISH allowed the simultaneous observation of nucleoli and ribosomal genes during interphase (Fig. 3D,F,H,J). The 18S-5.8S-25S and 5S ribosomal genes were located simultaneously on the interphase nuclei from quiescent and growing roots of different length. The 5S rDNA genes showed no nucleolar association (Fig. 3C). However, the 18S-5.8S-25S hybridisation signals were associated to nucleoli in all the stages of sprouting (Fig. 3D,F,H,J). Up to eight rDNA signals, each one associated to a single nucleolus, were detected exceptionally in unsprouted root cells (Fig. $3 \mathrm{D})$. This indicates that no ribosomal genes cluster were silenced in this species. However nucleolar fusion was most frequently observed (Figs. $3 \mathrm{~F}, \mathrm{H}, \mathrm{J}$ and 4$)$. In a low percentage of cells, all NORs (pTa71 sites) were found associated to a single large nucleolus (see Fig. 3F).

Silver staining of nucleoli and fibrillarin immunostaining were performed to determine how many nucleoli were active in sugarcane cells. Although a maximum of eight nucleoli per nucleus could be expected from the results of FISH, the values recorded varied between one single and seven nucleoli of different sizes, with an average of three nucleoli per nucleus (Fig. 4D). All nucleoli in the same nucleus showed a similar degree of staining after either fibrillarin immuno-staining or silver impregnation, independently of size, morphology and number of NORs they contained, suggesting a similar state of activity for all of them (Figs. 4A,B,C).

\section{Evolution of rDNA gene clusters and nucleoli during sprouting}

The FISH preparations clearly revealed changes in the condensation and organisation of the ribosomal genes during the process of sprouting, associated with the activation of cells and their entry into proliferation. These changes correlated with 

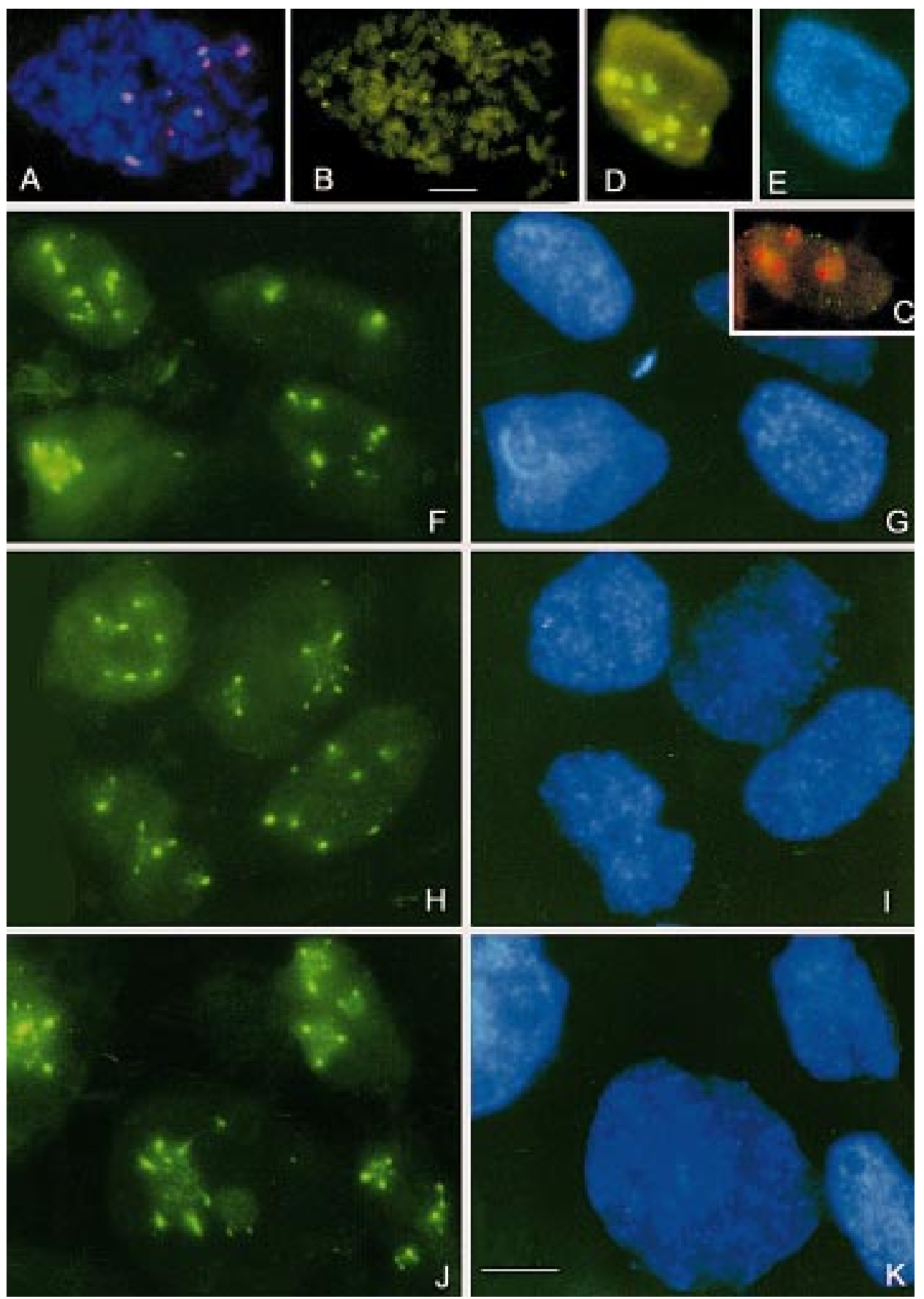

Fig. 3 - Localisation of ribosomal genes in sugarcane by FISH. A, B and C: simultaneous detection of the major rDNA genes with probe pTa71 labelled with rhodamine, and 5S rDNA genes with pTa794 labelled with FITC in proliferating cells. A and B: prometaphase showing eight NORs of different sizes in terminal positions, counterstaining with the DAPI-stained chromosomes (A). Eight $5 \mathrm{~S}$ sites were detected in different chromosomes (B). Bar corresponds to $10 \mu \mathrm{m}$. C: interphase nucleus showing all the NORs signals (red) associated to the three nucleoli and the eight $5 \mathrm{~S}$ sites (green) dispersed in the nucleus. D to K: distribution of the ribosomal genes in quiescent roots meristems (D) and roots of $2 \mathrm{~mm}(\mathrm{~F}), 5 \mathrm{~mm}(\mathrm{H})$ and $15 \mathrm{~mm}(\mathrm{~J})$ lengths. E, G, I, and $\mathrm{K}$ correspond to DAPI staining of the same cells. The micrographs illustrate the decondensation of ribosomal genes, which form single knobs in the quiescent nucleoli of the dry primordia (D) along the sprouting process $(\mathrm{F}, \mathrm{H}, \mathrm{J})$. The inactive condensed genes in the active nucleolus form either large signals at its periphery or small internal signals, while the active ones produce a diffuse fluorescent staining of the nucleolus (F,J). Bars correspond to $10 \mu \mathrm{m}$. 

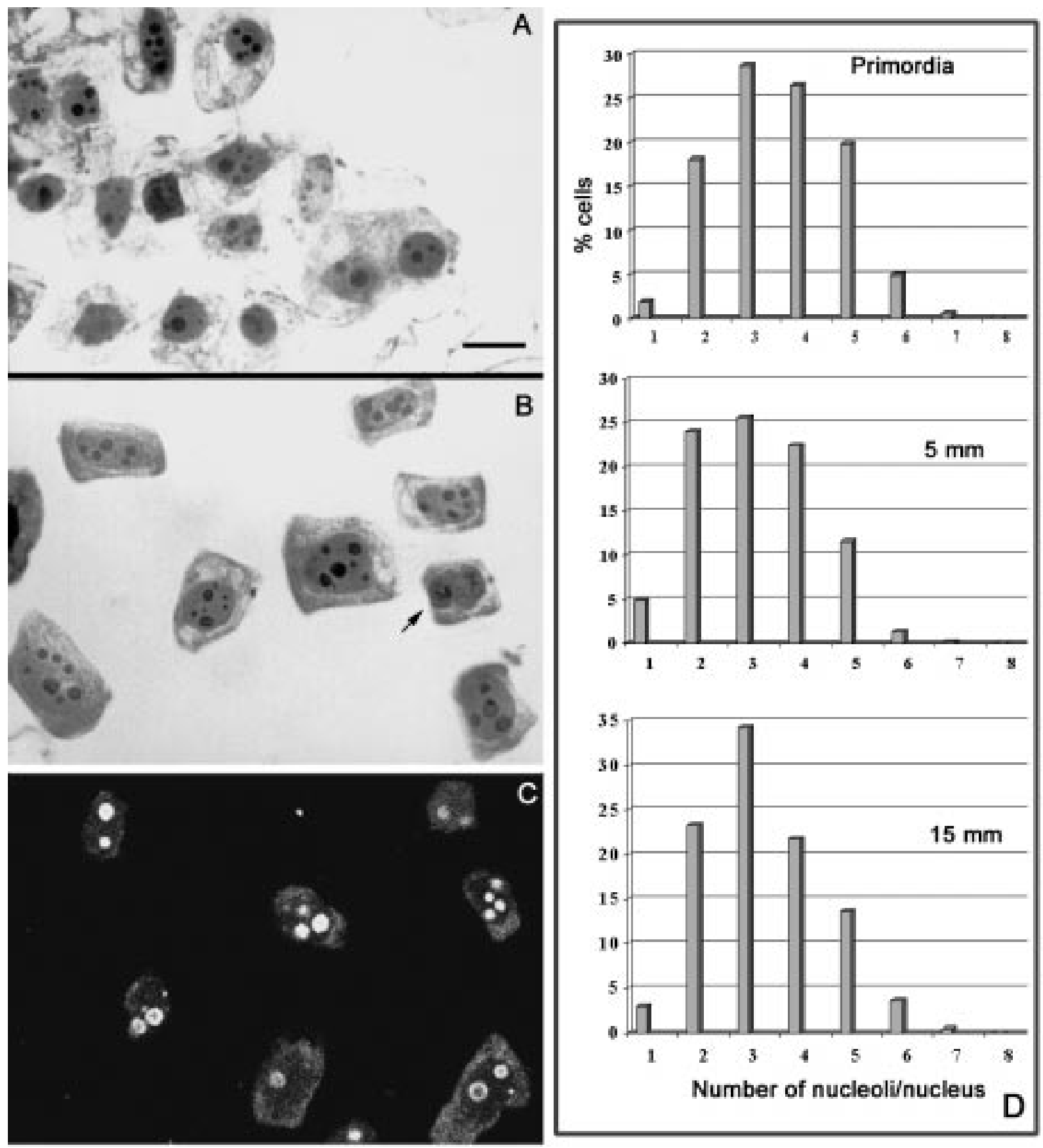

Fig. 4 - Variation of the number of nucleoli during sprouting. A and B: nucleolar silver stainings of quiescent and $5 \mathrm{~mm}$ roots. A variable number of nucleoli per nucleus with different sizes, are evident in both cases. The arrow in B points to a telophase. C: antifibrillarin labelling of cells from a $5 \mathrm{~mm}$ root. Bars correspond to $10 \mu \mathrm{m}$. D: Distribution of cells according to their different number of nucleoli in quiescent primordia and roots of $5 \mathrm{~mm}$ and $15 \mathrm{~mm}$ length. Values were significantly different between quiescent and proliferating (either $5 \mathrm{~mm}$ or $15 \mathrm{~mm}$ ) roots, but not between the proliferating roots $(P<0.05)$.

changes in the fine structure of the nucleolar domains observed by electron microscopy.

In the quiescent cells of the unsprouted root pri- mordia, the FISH signals for the major rDNA genes were associated to the small inactive condensed nucleoli. Usually there was a large single 
signal per nucleolus, whose location was mostly internal, but sometimes peripheral. No staining was observed in other nucleolar components (Figs. 3D,5B). Silver staining revealed a variable number of nucleoli per nucleus in them (from 1 to 7), being 3 and 4 the most commonly observed (Fig. 4A,D). The organisation of the rDNA condensed spots was very similar in the different cells of the quiescent blastema, in correlation with their common cell cycle phase $\left(\mathrm{G}_{0}\right)$ and metabolic activity, as they were inactive (Figs. 1,3D). After soaking, nucleolar activation was accompanied by a process of decondensation of the rDNA gene foci. The number of FISH signals per nucleolus increased and their relative sizes decreased. Usually there were small internal signals interconnected with each other, and with the largest ones at the nucleolar periphery, some of the later clearly protruding from the nucleolar body. There was also a process of nucleolar fusion during the activation of the root blastema, as demonstrated by the statistical analysis of the silver stainings, which demonstrated that the number of nucleoli in actively proliferative meristems statistically decreased $(p<0.05)$ in relation to quiescent primordia, while no differences existed between growing roots of different lengths (Fig. 4D).

In steady state proliferating cells, the nucleoli displayed two types of signals: very small signals interconnected forming a network inside the nucleolar body, which produced a diffusse signal in the case of highly active nucleoli and bright peripheral or, very rarely, internal signals probably corresponding to condensed non-active ribosomal genes (Thompson et al., 1997) (Figs. 3F,J).

Clear differences were observed in the distribution of the rDNA foci between the cycling cells, probably correlating with the cell cycle position in each case (see Figs. 3F,H,J), although all the nucleoli in the same nucleus displayed a similar pattern of decondensation and distribution of rDNA foci.

\section{Ultrastructural organisation of nucleolar domains in quiescent cells and during sprout- ing}

The nucleoli in the quiescent unsoaked nucleus showed a similar organisation in all the cells of the dry primordium with their main components segregated. They presented two characteristic features: the lack of condensed chromatin inclusions in their FC (Fig. 5A) and the constant presence of large CBs constituting the only nucleolar domain containing splicing proteins (Fig. 5C,D,E,F).

In ultrathin sections, the quiescent nucleoli appeared dense and degranulated and presented a clear segregation of their components (Fig. 5 A,C). They were surrounded by a clear halo, in which light fibres radiating from the nucleolus were evident (Fig. 5 A,C,E). These fibrils disappeared after water activation. They lacked a GC and were made up of only two of the canonical nucleolar domains: 1) a very compact DFC containing ribonucleoproteins and fibrillarin, as demonstrated by EDTA (Fig. 5E) and immunofluorescence (not shown) stainings; in which scarce nucleolar PG were observed after EDTA staining (Fig. 5E); and 2) a large $\mathrm{FC}$ in the core of the nucleolus containing the rDNA genes (Fig. 5A), corresponding to the hybridisation sites detected by FISH (Fig. 5B). The FC showed a light contrast, lacked the dense chromatin inclusions described in other plant species (Risueño and Moreno Díaz de la Espina, 1979, Fakan and Deltour, 1981) and was in tight contact with the extranucleolar chromatin masses (Fig. 5A,D). In some cases, a perinucleolar condensed chromatin mass was observed in close contact with the clear FC, constituting the so-called nucleolus-associated chromatin (NAC) (Fig. 5A,C,D), a typical structure of some plant nucleoli (Moreno Díaz de la Espina et al., 1992), which also contained ribosomal genes as demonstrated by FISH (Fig. 3D). It sometimes appeared attached to the nuclear envelope (Fig. 5A). This structure presented a higher contrast and condensation state than the internal FC, and it also bleached after EDTA staining (Fig. 5E).

These nucleoli displayed an additional domain constituted by one or more $\mathrm{CBs}$ protruding from the nucleolus or associated to their periphery, whose coiled fibres were in tight contact with those of the DFC (Fig. 5A,C,E). This is a feature of some plant species, including sugarcane, in which we have demonstrated that the number of $\mathrm{CBs}$ bound to the nucleolus remained constant independently of cell activity (Acevedo et al., 2002). The ultrastructural organisation of their coiled fibres and their composition, differentiated them from the FCs, as they contained ribonucleoproteins (Fig. 5E) and splicing factors (Fig. 5F), but they did not hybridised with the ribosomal 


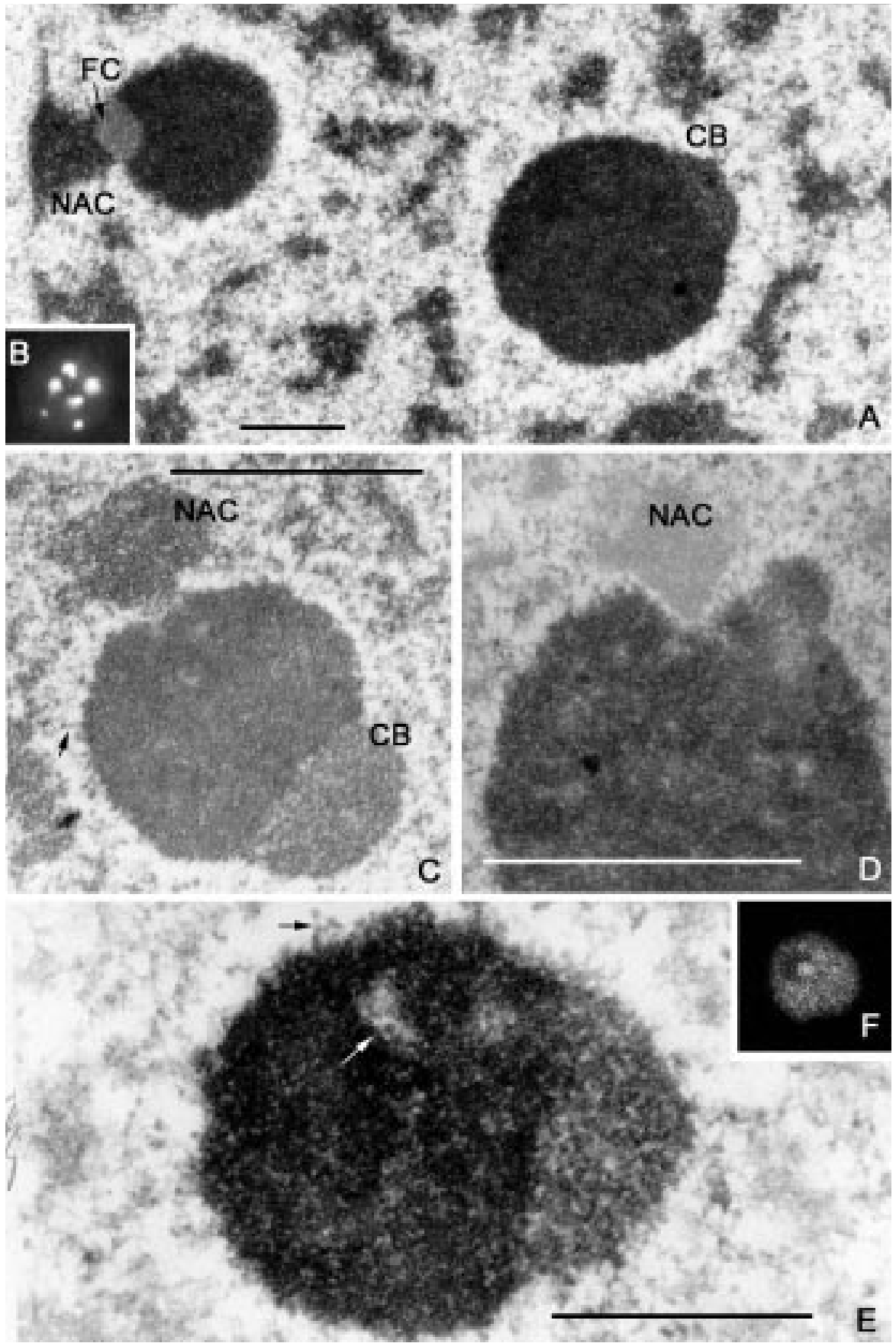

Fig. 5 - Ultrastructural organisation of the nucleolus in quiescent meristematic cells. All micrographs correspond to dry primordia except $\mathrm{D}$ which shows a nucleolus from a soaked primordia. A and C conventional electron micrographs. D and E: EDTA stainings. B: FISH with pTa71 probe. F: Y12 immunolabeling. The compact quiescent nucleolus is segregated with the DFC clearly segregated from the FC and the nucleolar CB. It appears surrounded by a clear halo in which fibres radiating from the nucleolus are evident (small arrows). There is a single FC per nucleolus, as demonstrated by FISH with pTa71 probe (B), connected with the condensed chromatin masses of the NAC (nucleolus associated chromatin) which sometimes appear connected with the nuclear envelope (A). The FC has a light contrast, different from that of the NAC. After EDTA staining preferential for ribonucleoproteins, the DFC appears deeply contrasted and show scarce nucleolar PG (arrow in E). This staining allows to discriminate clearly the bleached NAC masses from the CB (D) which appears contrasted according with their content in snRNPs $(\mathrm{D}, \mathrm{E})$ and splicing factors $(\mathrm{F})$. Bar in $\mathrm{A}, \mathrm{C}$ and $\mathrm{D}=1$ $\mu \mathrm{m}$. Bar in $\mathrm{E}=0.5 \mu \mathrm{m}$. probes (Fig. 5B). Coilin genes have not yet been demonstrated in plants and, besides anti-coilin antibodies are not reactive in these systems. For these reasons, immunostaining with Y12, recognising the $\mathrm{Sm}$ components of spliceosomal snRNPs, and 4G3 for U2B" splicing protein (not shown) were used to demonstrate that $\mathrm{CBs}$ are the only nucleolar domain containing these particles in both quiescent (Fig. 5F) and active (Fig. 6D) nucleoli (see also Acevedo et al., 2002).

24 hours after soaking, when root sprouts were not yet evident in the nodes, the network of condensed nuclear chromatin started decondensing. As the nuclear activity increased by water activa- 

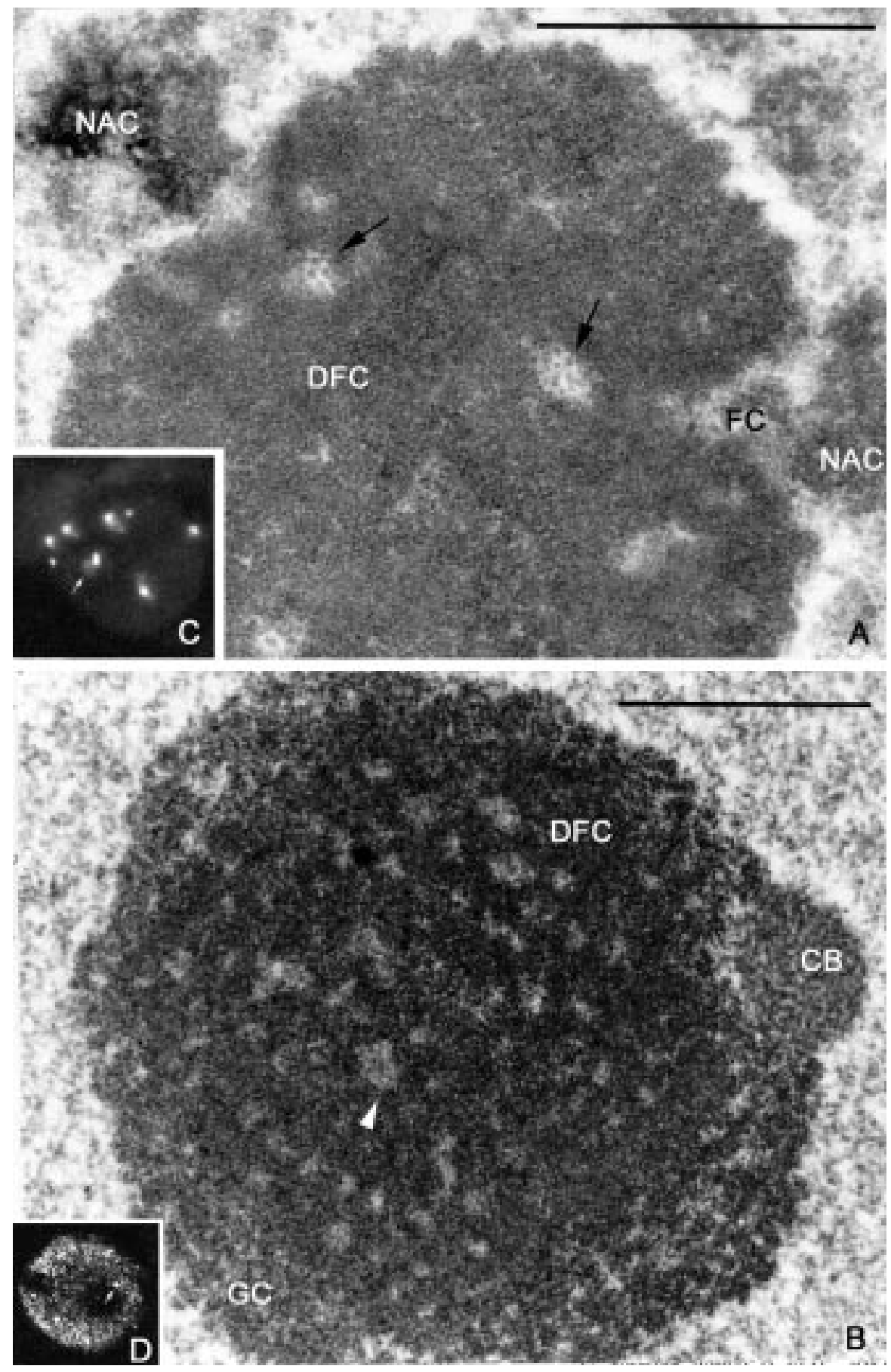

Fig. 6 - Ultrastructure of reactivating nucleoli. A: Electron micrograph of a reactivating nucleolus of a cell from the quiescent primordia after $24 \mathrm{~h}$ soaking. Two NAC masses in close contact with the clear FC are shown. Numerous perichromatin granules are observed in association with the decondesing FC (arrows). A scarce peripheral layer of GC stars forming at this stage. C: Shows a nucleus from a cell in a similar stage of sprouting, after FISH with pTa71 probe, in which a similar stage of decondensation of the NOR is shown (arrow). B: Nucleolus from a meristematic cell of a 2 $\mathrm{mm}$ root. Numerous and small clear FCs (arrow) surrounded by the DFC and an aboundant peripheral GC and nuclelusattached $\mathrm{CBs}$ are the typical nucleolar domains of this stage. D: Nucleus from a meristematic cell after Y12 immunostaining showing that $\mathrm{CBs}$ are the only nucleolar component containing snRNPs (arrows), which are also present in the nucleoplasm. Bars $=1 \mu \mathrm{m}$. tion, the nucleoli became looser and the halo around them disappeared. The large FC evolved to form smaller ones interconnected with each other and with the NAC masses in the nucleolar periphery (Figs. 5D, 6A). This localisation correlates with the results of FISH which detected the decondensing rDNA genes mostly inside the nucleolus, and the condensed ones in a peripheral location (Fig. 6C).

At higher magnifications, numerous nucleolar PG, deeply stained by EDTA, appeared associated to the nucleolar FCs during reactivation (Figs. 
5D,6A). These granules are not a constant nucleolar component in plants, but they form under physiological conditions, when nucleoli reinitiate their transcriptional activity. Thus they are typical nucleolar components of the recently reassembling early G1 (Bassy et al., 2000) and early germinating (Fakan and Deltour, 1981) nucleoli. A thin layer of granular component appeared at this state surrounding the extensive masses of the DFC, and the perinucleolar halo disappeared. In more advanced stages of activation, the FCs became more abundant and smaller, and did not show a significative accumulation of nucleolar PGs. The DFC became looser and a distinct abundant GC accumulated at the nucleolar periphery (Fig. 6B). Eventually, these three nucleolar components became fully intermingled (Fig. 7A). Well developed CBs were associated to the nucleolar periphery (Fig.6D). Although their sizes were smaller in relation to quiescent nucleoli, their number and composition were maintained constant (Acevedo et al., 2002). The CBs were clearly distinct from NAC-masses on view of their content in RNPs after EDTA staining (Fig.5D) and in splicing factors as revealed by $\mathrm{Y} 12$ and $4 \mathrm{G} 3$ immunostaining (Figs. 5F and 6D).

As active cells went into cell cycle and started dividing, nucleoli with different organisations were observed in the proliferative meristematic population. The nucleoli of cycling cells showed the typical ultrastructure described for active plant cells, with their components highly intermingled. They showed small and clear FCs, correlating with the small intranucleolar hybridisation sites detected by FISH (Fig. 7B), surrounded by a thin layer of dense fibrillar component corresponding to the diffuse intranucleolar FISH staining (Fig. 7A), and an aboundant granular component, containing pre-ribosomal particles, surrounding the DFC domains (Fig. 7A). CBs are a constant nucleolar component of cycling nucleoli in this species (Figs. 6B,6D and Acevedo et al., 2002). In some cases a nucleolar cavity, filled with ribonucleoproteins, formed and the nucleolus adopted the so-called vacuolated organisation described as a marker of high nucleolar activity (Fig. 7A) (Moreno Díaz de la Espina et al., 1980).

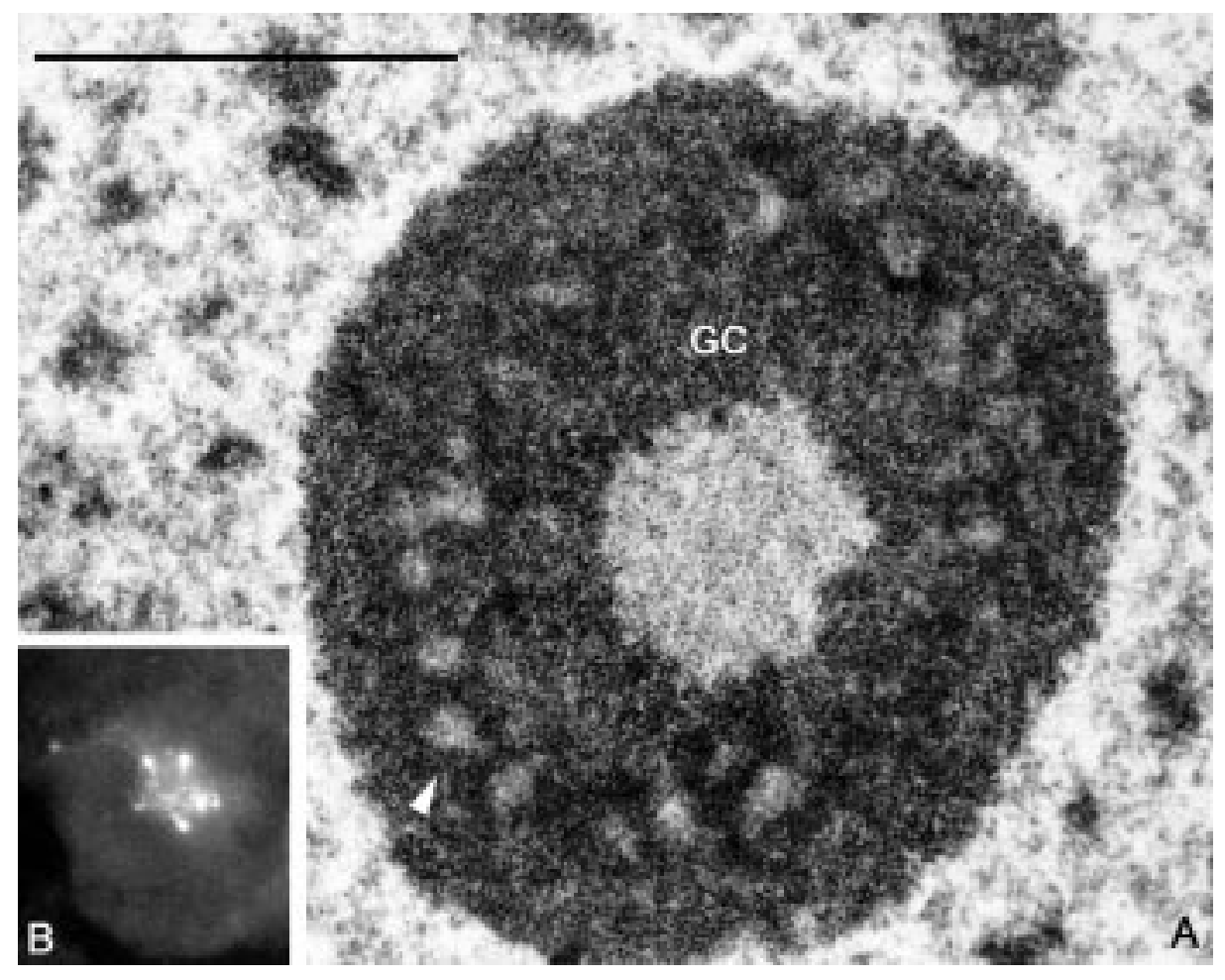

Fig. 7 - A: Highly active nucleoli from a steady-state proliferating cell with a central cavity and the three typical domains highly intermingled. Bar $=1 \mu \mathrm{m}$. B: Shows the distribution of nrDNA genes in a nucleolus with a similar stage of activity, after FISH with pTa71 probe. The condensed parts of the NOR are peripheral, while inside the nucleolus very small beads interconnected with each other and a diffuse staining are observed. 


\section{DISCUSSION}

\section{The rDNA loci of noble sugarcane}

Plant cells usually display ribosomal gene multiplicity. Its extent may vary from one to other inbred lines, as in maize (De la Torre and Colinas, 1978), and certainly among related species (Ingle and Sinclair, 1972; Maher and Fox, 1973). The present study confirms that the noble sugarcane has a single nucleolar organizer region (NOR) per haploid complement, located distal in a chromosome (D’Hont et al., 1998). Thus, FISH carried out by the whole wheat rDNA sequence showed that, in the octoploid genome $(2 n=8 x=8 n)$ of the Cristalina variety of the noble sugarcane, there were 8 NORs. The images obtained in metaphase, when the NORs are still dormant and condensed (Panzera et al., 1996), showed that there was some heterogeneity in signal size, probably because of the different number of genes in each of these NORs. The simultaneous visualization of nucleoli and NORs reveals the participation of multiple NORs in the formation of a single nucleolus. In them, the condensed part of the NORs usually remained peripheral to the common nucleolus, while the nucleolar core region contained the dispersed, and then potentially active, rDNA. Fusion of the protein components related to the maturation of the pre-rRNA in a common nucleolus formed by different individual NORs may be advantageous for the ribosomal RNA processing. However, the preferential fusion of small singleNOR nucleoli into larger ones, in the cycling cells $(p<0.05)$, may be only a physical consequence of the dispersion of rDNA genes and enlargement of the other nucleolar components as a result of active transcription.

The FISH images directly prove the functional redundancy of the rDNA genes in the sugarcane genome. The selective activation of some of the genes from the abundant set of them present in a NOR, apparently relies in their early decondensation. Thus, it can be induced by hypomethylating some NORs versus another ones in a cell (De la Torre et al., 1991), as well as by inhibiting chromosome condensation through preventing the synthesis of new proteins from mid telophase to early G1 (Fernández-Gómez et al., 1972; GiménezAbián et al., 1998). On the other hand, the restricted activation of a limited portion of the genes relies on shortage of the available transcription factors a particular cell has (Goodrich et al., 1996).

Visualization of the progressive undercondensation of nucleolar genes, at different times after the stimulation to proliferate, supports a role for rDNA decondensation in the activation of nucleolar transcription, and allowed a comparison with the ultrastructural data of NORs and FCs during the process.

\section{Plasticity of the nucleolar domains in relation to nucleolar gene expression during activation}

There is a consensus that the structure of the nucleolus is organised as a consequence of the activity of the tandemly repeats of rDNA genes in each case (Olson et al., 2000; Medina et al., 2000). Our results fully confirmed this proposition by demonstrating a correlation between cell cycle position, decondensation of rDNA genes and ultrastructural organisation of nucleolar domains during sprouting, and also revealed some peculiarities of the organisation of the nucleolar genes and domains in sugarcane in relation to other plant species.

Quiescent roots undergo dramatic metabolic changes during the process of sprouting. The quiescent cells of the root blastema are stoped in a pre-replicative $\left(\mathrm{G}_{0}\right)$ state and after water activation they need a massive synthesis of proteins for progression through the first post-quiescence cell cycle and later cell division. Although they have RNA polymerases, they need a great quantity of rRNAs to increase their number of ribosomes to perform protein synthesis (Morcillo and de la Torre, 1979).

As demonstrated by FISH, the quiescent $\mathrm{G}_{0}$ cells have all its rDNA repeats potentially active, i.e., associated to a nucleolus (Flavell et al., 1986), but they are transcriptionally inactive according with the biochemical and autoradiographical data in plant species which revealed a gap in rRNA synthesis during the first hours of root germination (van de Walle et al., 1969, Fakan and Deltour, 1981; Deltour, 1985). The rDNA repeats in each nucleolus are aggregated forming a single FC and without ultrastructural interactions with the rest of the nucleolar domains, which appear clearly segregated. These features are characteristic of most inactive plant nucleoli either in physiological conditions (Risueño and Moreno Díaz de la Espina, 1979; Fakan and Deltour, 1981; Deltour, 1985; Bassy et al., 2000) or after experimental inhibition of rRNA synthesis 
(Risueño et al., 1972; Giménez-Martín et al., 1973). In the quiescent nucleoli besides structural segregation of the different domains, there is also a sorting of the nucleolar components to different domains. rDNA genes are confined to the FC, and the snRNPs localise exclusively to the $\mathrm{CB}$. The quiescent DFC does not contain rDNA genes (see also Bassy et al., 2000 for onion), but it does contain argyrophilic proteins and the protein fibrillarin, involved in early rRNA processing, which is also a component of the nucleolar matrix (Moreno Díaz de la Espina, 1995). All these data confirm that the DFC of the quiescent nucleolus is not engaged in rRNA synthesis and early processing, but rather plays a role in storage of frozen factors and machineries for pre-rRNA synthesis to be used in the first post-quiescence cell cycle (den Boer and Murray, 2000) after water activation. Thus, according to the available data on RNA and protein synthesis in germinating roots, at least a part of the necessary enzymatic machineries already exist in the dry meristem (Jakobs and Bovey, 1969). The DFC could also correspond partly to the elements of the nucleolar matrix which will be involved not only in the storing of these nucleolar components, but also in the later architectural reorganisation of active ribosomal genes and the corresponding transcription and processing complexes, needed for their expression (Moreno Díaz de la Espina, 1995)

The progressive decondensing of rDNA genes during activation correlates with the rearrangement and later intermingling of the nucleolar domains. The activation of the single FC is accompanied by their disaggregation in smaller FCs and the appearance of nucleolar PG in their interface with the DFC, where rRNA synthesis and U3 association to the ribosomal precursors first occurs (Fakan et al., 1981; Bassy et al., 2000). Although the molecular composition of PG is unknown, except for their contents in RNPs, they are supposed to correspond to uncompletely processed pre-ribosomal particles. They are not present in more advanced stages of sprouting, except during the reassembling and activation of early $\mathrm{G}_{1}$ nucleolus in each cell cycle after mitosis, as reported in other plant species (Fakan et al., 1981; Bassy et $a l ., 2000)$. As they were also detected in the quiescent nucleolus, although in considerably lower amounts, at least some of them would not be synthesised during nucleolar activation, but would rather correspond to particles containing either the rDNA transcription machinery assembled in an inactive state as in the mitotic NORs (Roussel et al., 1996), and/or frozen unprocessed pre-ribosomal particles, or snoRNPs and proteins necessary for early rRNA synthesis and processing by quiescent $\mathrm{G}_{0}$ ribosomal genes.

In more advanced stages of root sprouting, the activity of nucleolar genes generates highly dynamic nucleoli with an extensive DFC, many and small FCS and a loose GC in their outer part. These three nucleolar domains become fully intermingled and generate a loose nucleolus with a central cavity. The distribution of the small FCs and the surrounding DFC ressambles very much that of the BrUTP-labelled foci of transcription of active plant nucleoli (Thompson et al., 1997). Thus, the differences in the arrangement and proportions of the different nucleolar domains, reflect the rates of transcription, processing and transport of rRNAs resulting in a different balance between them at different stages of sprouting.

In contrast with the dramatic variations produced in the domains involved in the nucleolar metabolism of ribosomal precursors, the nucleolar domain containing snRNP particles, i.e. the CBs, underwent no variations in their organisation or numbers during sprouting (Acevedo et al., 2002), supporting the view that they constitute storing or maturation sites for snRNP components, but they are not involved in their synthesis (Acevedo et al., 2002; Boudonck et al., 1998).

Plant cells have thousands copies of ribosomal genes (Panzera et al., 1996), but only a low proportion of them are active in the nucleolus (a 5\% was recently estimated in active pea meristems by González Melendi et al., 2001). According to our results, in sugarcane most inactive rDNA genes, corresponding to one or more NORs for each nucleoli, would form condensed perinucleolar knobs containing both the coding rRNA sequences and the intergenic spacers (Thompson et al., 1997), while the actively transcribing genes would have a diffusse distribution in the DFC, or form small foci, probably around FCs, which are structural components of the plant nucleolar matrix (Moreno Díaz de la Espina,1995), around which the rDNA transcription units are organised (Hozac et al., 1994). As our probe contains both the coding and intergenic sequences, we can not discriminate whether these foci contain the whole 
genes, or only the non-transcribed spacers, as suggested in other plant species (Thompson et al., 1997)

In contrast with the situation in other plants, sugarcane nucleoli do not have heterogeneous FCs with inclusions of condensed chromatin, neither in quiescent nor in proliferating cells, in spite of the intense intranucleolar signals produced by FISH in quiescent and moderately active nucleoli, similar to those found in inactive or low active nucleoli of other monocot and dicot species (Risueño and Moreno Díaz de la Espina, 1979, Fakan and Deltour, 1981; Motte et al., 1991). Apparently, this feature does not correlate with differences in the rDNA gene contents of the species, a trait which to our knowledge is unknown in sugarcane.

\section{ACKNOWLEDGEMENTS}

We wish to thank Dr T. Martin (Chicago, Illinois) for the Y12 serum, Dr R. Ochs (La Jolla, California) for the S4 serum, the Instituto de Investigaciones de la Caña de Azúcar (INICA) Cuba, for the sugarcane stalks, Mrs M.Carnota and Mrs N. Fontúrbel for expert technical assistance. This work was supported by the Spanish MCYT (Projects PB98-0647 and BMC2001-2195) and by the CSIC/CITMA Agreement (Project 99CU0010). Ricardo Acevedo was financed with a Mutis fellow by the Spanish Agency of International Cooperation (AECI). Our thanks to Beryl Lygus for linguistic assistance.

\section{REFERENCES}

Acevedo R., Samaniego R., and Moreno Díaz de la Espina S.: Coiled bodies in nuclei from plant cells evolving from dormancy to proliferation. Chromosoma 110, 559-569, 2002.

Bassy O., Jiménez-García L.F., Echeverría O.M., VázquezNín G.H., and Moreno Díaz de la Espina S.: High resolution detection of rRNA and rDNA in plant nucleoli with different activities by in situ hybridization. Biol. Cell 92, 59-70, 2000.

Boudonck K., Dolan L., and Shaw P.J.: Coiled bodies numbers in the Arabidopsis root epidermis are regulated by cell type, developmental stage and cycle parameters. J. Cell Sci. 111, 3687-3694, 1998.

Bryant T.R.: DNA synthesis and cell division in germinating onion II. Mitotic cycle and DNA content. Caryologia 22, 139$148,1969$.
De la Torre C., Colinas F.: Nucleologenesis and number of ribosomal RNA genes in maize. Genetica (Utrech) 49, 219233, 1978.

De la Torre C., Giménez-Abián J.F., González-Fernández A.: Dominance of a NOR (nucleolar organizer region) over its allele and over its sister NOR after asymmetric 5-azacytidine substitution in plant chromosomes. J. Cell Sci. 100, 667-674, 1991.

De la Torre C., Giménez-Martín G.: The Nucleolar Cycle. In: The Nucleolus. (Eds. E.G. Jordan and C.A. Cullis). Society for Experimental Biology. Cambridge University Press. Cambridge. U.K. pp. 153-157, 1982.

Deltour R.: Nuclear activation during early germination of the higher plant embryo. J. Cell Sci. 75, 43-83, 1985.

Den Boer B.G.W., and Murray J.A.U.: Triggering the cell cycle in plants. Trends in Cell Biol, 10, 245-250, 2000.

D’Hont A., Ison D., Alix K., Roux C., and Glaszman J.C.: Determination of basic chromosome numbers in the genus Saccharum by physical mapping of ribosomal RNA genes. Genome 41, 221-225, 1998.

Fakan S., and Deltour R.: Ultrastructural visualization of nucleolar organizer activity during early germination of Zea mays L. Exp. Cell Res. 135, 277-282, 1981.

Flawell R.B., O`Dell M., Thompson W.F., Vincentz M., Sardana R., and Barker R.F.: The differential expression of ribosomal RNA genes. Phil. Trans. R. Soc. Lond. B 314, 385-397, 1986.

Fernández-Gómez M.E., De la Torre C., and Giménez-Martín G.: Accelerated nucleolar reorganization with shortened anaphase and telophase during cycloheximide inhibition of protein synthesis in onion root cells. Cytobiol. 2, 117-124, 1972.

Gaudino R.J., and Pikaard C.S.: Cytokinin induction of RNA polymerase I transcription in Arabidopsis thaliana. J. Biol. Chem. 272, 6799-6804, 1977.

Gerlach W.L., and Bedrook J.R.: Cloning and characterisation of ribosomal RNA genes from wheat and barley. Nucleic Acids Res. 7, 1869-1885, 1979.

Gerlach W.L., andDyer T.A.: Sequence organisation of the repeating unit in nucleus of wheat that contain 5SrRNA genes. Nucleic Acids Res. 8, 4851-4865, 1980.

Giménez-Abián M.I., Giménez-Abián J.F., Cuadrado A., Pelayo H.R., Giménez-Martín G., and De la Torre C.: The development of intraspecific dominance in some nucleolar organizer regions of plants. In: Plant Cell Proliferation and its Regulation in Growth and Development. (Eds. J.A. Bryant and D. Chiatante). John Wiley \& Sons Ltd, Sussex, UK. pp. 167-183, 1998.

Giménez-Martín G., Risueño M.C., Fernández-Gómez M.E., and Ahmadian P.: Effect of cordycepin on the fine structure of interphase nucleoli in plant cells. Cytobiologie 7, 181-192, 1973.

González-Melendi P., Wells B., Beven A.F., and Shaw P.J.: Single ribosomal transcription units are linear, compacted Chritstmas trees in plant nucleoli. Plant J. 27, 223-233, 2001. 
Goodrich J.A., Cutler G., and Tjian R.: Contacts in context: promoter specificity and macromolecular interactions in transcription. Cell 84, 825-830, 1996.

Highett M.I., Rawlins D.J., and Shaw P.J.: Different patterns of rDNA distribution in Pisum sativum nucleoli correlate with different levels of nucleolar activity. J. Cell Sci. 104, 843-852, 1993.

Hozák P., Cook P.R., Schöfer C., Mosgöller W., and Wachtler F.: Site of transcription of ribosomal RNA and intranucleolar structure of Hela cells. J. Cell Sci. 107, 639-648, 1994.

Ingle J., and Sinclair J.: Ribosomal RNA genes and plant development. Nature 235, 30-32, 1972.

Jakob K.M., and Bovey F.: Early nucleic acids and protein syntheses and mitoses in the primary root tips of germinating Vicia faba. Exp. Cell Res. 54, 118-126, 1969.

Karagiannis C.S., and Papelis A.J.: Effects of abscisic acid, gibberellic acid, indoleacetic acid and kinetin on selective ribosomal cistron regulation in quiescent and senescent onion leaf base tissue. Mech. Ageing Dev. 176, 145-155, 1994.

Leicht A.R., Mösgoller W., Shi M., and Heslop-Harrison J.S.: Different patterns of rDNA organisation at interphase in nuclei of wheat and rye. J. Cell Sci. 101, 751-757, 1992.

Maher E.P., and Fox D.P. Multiplicity of ribosomal RNA genes in Vicia species with different nuclear DNA contents. Nature New Biol. 245, 170-172, 1973.

Martín M., Moreno Díaz de la Espina S., and Medina F.J.: Immunolocalisation of DNA at nucleolar structural components in onion cells. Chromosoma 98, 368-377, 1989.

Medina F.J., Cerdido A., and de Cárcer G.: The functional organisation of the nucleolus in proliferating plant cells. Eur. J. Histochem. 44, 117-131, 2000.

Medina F.J., Risueño M.C., and Moreno Díaz de la Espina S.: 3D Reconstruction and Morphometry of Fibrillar Centres in plant cells in relation to nucleolar activity. Biol. Cell 48, 31-38, 1983.

Melera P.W.: Nucleic Acid metabolism in germinating onion. Plant Physiol. 48, 73-81, 1971.

Mineur P., Jennane A., Thiry M., Deltour, R, and Goessens G.: Ultrastructural distribution of DNA within plant meristematic cell nucleoli during activation and the subsequent inactivation by a cold stress. J. Ultras. Biol. 123, 199-210, 1998.

Morcillo G., and De la Torre C.: Control of mitotic chromosome condensation and of the time of nucleolar formation in meristems by short life proteins. Protoplasma 99, 221-228, 1979.

Moreno Díaz de la Espina S.: Nuclear matrix isolated from Plant cells. Int. Rev. Cytol. 162B, 75-139, 1995.

Moreno Díaz de la Espina S., Medina F.J., and Risueño M.C.: Correlation of nucleolar activity and nucleolar vacuolation in plant cells. Eur. J. Cell Biol. 22, 724-729, 1980.

Moreno Díaz de la Espina S., Mínguez A., Vázquez-Nín G.H., and Echeverría O.M.: Fine structural organisation of a nonreticulate plant cell nucleus. An ultracytochemical and immunocytochemical study. Chromosoma 101, 311-321, 1992.
Motte P.M., Loppes R., Menager M., and Deltour R.: Three-dimensional Electron microscopy of ribosomal chromatin in two higher plants: A cytochemical, immunocytochemical and in situ hybridisation approach. J. Histochem. Cytochem. 39, 1495-1508, 1991.

Olson M.O.J., Dundr M., and Szebeni A.: The nucleolus: and old factory with unexpected capabilities. Trends Cell Biol. 10, 189-196, 2000.

Panzera F., Giménez-Abián M.I., López-Sáez J.F., GiménezMartín G., Cuadrado A., Shaw P.J., Beven A.F., Cánovas J.L., De la Torre C.: Nucleolar organizer expression in Allium cepa L. chromosomes. Chromosoma 105, 12-19, 1996

Pederson T.: The plurifunctional nucleolus. Nucleic Acids Res. 26, 3871-3876, 1998.

Reeder R.H.: Mechanims of nucleolar dominance in animals and plants(a review). J. Cell Biol. 101, 2013-2016, 1985.

Risueño M.C., Fernández-Gómez M.E., De la Torre C., and Giménez-Martín G.: Effects of Ethidium Bromide on the fine structure of the nucleolus in plant cells. J. Ultrastruct. Res. 39, 163-172, 1972.

Risueño M.C., and Moreno Díaz de la Espina, S.: Ultrastructural and cytochemical study of the quiescent root meristematic cell nucleus. J. Submicr. Cytol. 11, 85-98, 1979.

Rost T.L., and Bryant J.A.: Root organisation and gene expression patterns. J. Exp. Bot. 47, 1613-1628, 1996.

Roussel P.C., André L., Comai, L., and Hernández-Verdún D.: The rDNA transcription machinery is assembled during mitosis in active NORs and absent in inactive NORs. J. Cell Biol. 133, 235-246, 1996.

Sans J., Giménez-Martín G., and De la Torre C.: Onset of cell proliferation in dormant roots of Allium cepa L. bulbs. Kinetic analysis. Biol. Cell 38, 95-104, 1980.

Sokal R.R., and Rohlf F.J.: Biometry. (Ed W.H. Freeman and Co) San Francisco. USA.

Thompson W.F., Beven A.F., Wells B., and Shaw P.J.: Sites of rDNA transcription are widely dispersed through the nucleolus in Pisum sativum and can comprise single genes. Plant $\mathrm{J}$. 12, 571-581, 1997.

Sussex I.M.: Dormancy and development. In: Dormancy and developmental arrest. Experimental analysis in plantas and animals. (Ed. M.E. Clutter). Academic Press, New York. pp. 297-301, 1978.

Van de Walle C., and Bernier G.: The onset of cellular synthetic activity in rotos of germinating corn. EXP. Cell Res. 55, 378-384, 1969.

Vant't Hof J.: Control of the cell cycle in higher plants. In: Cell cycle controls (Eds. Padilla G.M,. Cameron I.L., and Zimmerman A.). Academic Press, New York. pp. 77-85, 1974

Vázquez-Nín G.H., Echeverría O.M., Mínguez A., Moreno Díaz de la Espina S., Fakan S., and Martín T.E.: Ribonucleoprotein components of root meristematic cell nuclei of the tomato characterised by application of mild lossening and immunocytochemistry. Exp. Cell Res. 200, 431-438, 1992. 